Podsumowując dwudniowe obrady, dr hab. Zbigniew Osiński zwrócił uwagę na bogactwo problematyki oraz wysoki poziom merytoryczny referatów. Wszystkie wystąpienia prelegentów cieszyły się dużą popularnością wśród uczestników. Szczególną wartością konferencji, oprócz zapoznania się z wynikami ostatnich badań w zakresie szeroko rozumianej informacji naukowej i bibliotekoznawstwa, była możliwość wymiany doświadczeń między praktykami i teoretykami działalności bibliotecznej. 0 sukcesie konferencji zdecydował również trafny dobór referatów, duże zaangażowanie środowiska naukowego i bibliotecznego oraz ożywiona dyskusja nad poruszaną problematyką konferencji.

\section{Grażyna Piechota}

Instytut Bibliotekoznawstwa i Informacji Naukowej Uniwersytetu Marii Curie-Skłodowskiej w Lublinie
$D^{\prime}$ nia 19 października 2012 r. odbyła się konferencja, ciesząca się zainteresowaniem bibliotekarzy opiekunów cennych kolekcji książkowych, historyków, historyków książki i sztuki, jak również lub przede wszystkim bibliofilów. Organizatorem konferencji było Muzeum Zamkowe w Malborku, a głównym jego reprezentantem Aleksandra Siuciak. Po rejestracji uczestników konferencji goście zostali przywitani przez dyrektora muzeum Mariusza Mierzyńskiego oraz Elżbietę Stefańczyk, przewodniczącą Stowarzyszenia Bibliotekarzy Polskich, które objęło patronatem honorowym to spotkanie.

Konferencja została podzielona na trzy sesje, w czasie których przewidziano prezentację 16 referatówprzedstawicieli bibliotek, muzeów i ośrodków naukowych.

\section{Konferencia naukowa „Księgozbiory rozproszone. Losy księgozbiorów historycznych po Il wojnie światowej" (Malbork, 19 października 2012 r.)}

DOI: $10.12775 /$ TSB. 2013.015

Pierwszą sesję otworzył referat Hanny Łaskarzewskiej (Polskie Towarzystwo Bibliologiczne) zatytułowany „Krajobraz po bitwie - skala zniszczeń i rozproszeń polskich księgozbiorów historycznych w wyniku II wojny światowej". Autorka podjęła się przedstawienia zarysu obszernej tematyki zniszczeń i rozproszenia polskich i poniemieckich księgozbiorów, które znajdowały się na terenie Generalnego Gubernatorstwa. Niestety, brak inwentarzy, spisów, jakichkolwiek wykazów 
nawet najcenniejszych księgozbiorów nie pozwala badaczom na dokładne oszacowanie strat wynikłych z działań II wojny światowej. Na podkreślenie zasługuje fakt, że właśnie zbiory zabezpieczone stały się fundamentem nowo tworzonych księgozbiorów uniwersyteckich, m.in. Biblioteki Uniwersyteckiej w Toruniu.

Kolejny referat wygłosił dr hab. Ryszard Nowicki, prof. UKW. Dotyczył on działalności Zbiornicy Księgozbiorów Zabezpieczonych w Katowicach w latach 1947-1955. W swoim wystąpieniu prelegent wymienił m.in. Józefa Grycza oraz osoby pracujące na rzecz zabezpieczenia zbiorów. Przybliżony został zakres zadań zbiornicy katowickiej, która działała obok tych utworzonych w Gdańsku, Wrocławiu, Poznaniu, Krakowie czy Szczecinie. Podobnie jak przedmówczyni, referent przytoczył najważniejsze akty prawne i instytucje nadzorujące akcję zabezpieczania opuszczonych zbiorów w trakcie II wojny światowej. Prelegent dokonał próby oceny działalności, jej celowości wraz z wszelkimi związanymi z tym konsekwencjami, m.in. obecne problemy z badaniami księgozbiorów rozproszonych.

Aleksandra Siuciak (Muzeum Zamkowe w Malborku) z wystąpieniem zatytułowanym „Biblioteki zamkowe losy księgozbiorów Towarzystwa Odbudowy i Upiększenia Zamku Malborskiego oraz Zarządu Odbudowy
Zamku po II wojnie światowej. Próba rekonstrukcji" wprowadziła słuchaczy w tematykę bibliotek zamkowych ze szczególnym uwzględnieniem losów dwóch księgozbiorów, które były warsztatem pracy dla konserwatorów i pracowników muzeum pruskiego. Autorka podkreśliła, że jednym z trudniejszych zadań jest odnalezienie pozostałości po księgozbiorach malborskich w książnicach polskich ze względu na brak danych o ich strukturze proweniencyjnej. Dalsze wnioski na temat zawartości treściowej zostaną upublicznione po zrekonstruowaniu zasobności omawianej biblioteki zamkowej.

Marta Kurzyńska (Muzeum Narodowe w Szczecinie) w referacie „Powojenne losy księgozbioru Biblioteki Muzeum Narodowego w Szczecinie jako jedno ze świadectw perturbacji poniemieckich księgozbiorów na Ziemiach Odzyskanych" przedstawiła dzieje muzealnictwa szczecińskiego, co było wprowadzeniem do prezentacji początków biblioteki. O profilu omawianej książnicy zdecydowały zbiory lokalnych towarzystw naukowych, gdzie dominowały prace $\mathrm{z}$ historii sztuki i przyrodnicze. Duży wpływ na obecny kształt librarii miały także Wojewódzka Komisja Opieki nad Książkami (1945-1947) oraz Zbiornica Księgozbiorów Zabezpieczonych w Szczecinie (1947-1950).

W kolejnym referacie „Teki Marii Quirini jako źródło do dziejów ponie- 
mieckich księgozbiorów na Pomorzu Zachodnim" jego autor - Przemysław Garlicki (Książnica Pomorska w Szczecinie) bardzo szczegółowo zaprezentował bogaty materiał źródłowy zawarty w tekach kierownika Zbiornicy Księgozbiorów Zabezpieczonych w Szczecinie - Marii Quirini.

Dr Agnieszka Borysowska (Książnica Pomorska w Szczecinie) zatytułowała swoje wystąpienie „Powojenne losy szczecińskich księgozbiorów historycznych na przykładzie biblioteki Andreasa Müllera Greifenhagiusa (1630-1694)". Po przedstawieniu życia orientalisty, teologa i filozofa ukazano losy jego prywatnego księgozbioru przed i po 1945 r. Autorka nadal prowadzi poszukiwania książek należących do Andreasa Müllera Greifenhagiusa w dużych bibliotekach naukowych, jednocześnie apelując o szerszą informację o zbiorach historycznych wchodzących w skład ich najstarszych kolekcji.

Drugą sesję zapoczątkował referat Michała Spandowskiego z Biblioteki Narodowej o polskich zbiorach inkunabułów zniszczonych, przemieszczonych i rozproszonych $\mathrm{w}$ trakcie i w wyniku II wojny światowej. Po wspomnieniu działalności Kazimierza Piekarskiego i Alodii Kaweckiej-Gryczowej prelegent omówił największe straty wśród inkunabułów, na czele wymieniając Bibliotekę Narodową oraz duże książnice świeckie, jak i ko- ścielne. Jednocześnie podkreślił fakt niewytłumaczalnego powiększenia zasobów niektórych bibliotek naukowych, które przed wojną dysponowały znikomą liczbą paleotypów, a już po II wojnie światowej mogły poszczycić się dość sporą kolekcją. Referent podkreślił, że w zbiorach naukowych nadal znajdują się inkunabuły uznane niegdyś za stracone.

Kolejny referat „Inkunabuły bibliotek Pomorza Zachodniego i ich powojenne losy" - korespondujący z poprzednim - zaprezentowała Agata Michalska (Książnica Pomorska w Szczecinie). Referentka przybliżyła dotychczasowe ustalenia na temat rozproszenia zbiorów pomorskich, w tym Biblioteki Kapitulnej w Kamieniu Pomorskim, Biblioteki Miejskiej w Szczecinie i zbiorów z zamku Ostenów-Bismarców w Płotach, nie pomijając kolekcji przechowywanych w Jasienicy czy Stargardzie Szczecińskim.

Jako następny wystąpił dr Arkadiusz Wagner (Uniwersytet Mikołaja Kopernika w Toruniu). Prelegent omówił losy zaginionej części biblioteki łańcuchowej w Złotoryi, której fragment został odnaleziony w Bibliotece Polskiej w Paryżu. Po przedstawieniu dziejów zbiorów parafialnych autor nie był w stanie stwierdzić, z powodu braku dokumentacji, w jaki sposób cztery woluminy znalazły się w stolicy Francji. Nie przeszkodziło mu to jed- 
nak w zaprezentowaniu efektownych opraw zachowanych druków.

W sesji drugiej swój referat wygłosił także dr Zdzisław Gębołyś (Uniwersytet Śląski w Katowicach). Prelekcja pt. „Losy księgozbiorów mniejszości niemieckiej w Polsce po II wojnie światowej" została podzielona na kilka części: mniejszość niemiecka w Polsce, biblioteki mniejszości niemieckiej w Polsce, biblioteki mniejszości niemieckiej w Katowicach, postulaty badawcze. Swoje wnioski referent oparł na szczegółowych danych statystycznych. W przyszłości pragnie przeprowadzić pogłębione badania proweniencyjne i ocenić faktyczny stan zachowania tych księgozbiorów.

Sesję zamknęła reprezentantka Biblioteki Głównej Politechniki Gdańskiej Barbara Ząbczyk-Chmielewska z wystąpieniem „Księgozbiór Towarzystwa Przyrodniczego w Gdańsku znane i nieznane losy". Referentka przedstawiła profil gromadzonego przez Towarzystwo Przyrodnicze w Gdańsku księgozbioru, na który złożyły się głównie dzieła z zakresu fizyki, chemii, botaniki itd. Podczas II wojny światowej, w czasie transportu, zbiory zajmowały 500 skrzyń. Obecnie zachowało się około 400 woluminów, w tym 209 starych druków. Już te dane pozwalają stwierdzić znaczne rozproszenie i zniszczenie cennej kolekcji.

Trzecią sesję rozpoczął prof. dr hab. Wiesław Sieradzan (Uniwersy- tet Mikołaja Kopernika w Toruniu), który w referacie „Uzupełnienia do rekonstrukcji księgozbioru Bernharda Schmida" dokonał podsumowania dotychczasowych badań nad biblioteką konserwatora malborskiego (por. W. Sieradzan, Bernhard Schmid (1872-1947). Księgozbiór prywatny ostatniego niemieckiego konserwatora zamku w Malborku, Malbork 2011). Następnie prelegent wskazał dodatkowe miejsca przechowywania fragmentów zbiorów Schmida, w tym bibliotekę Muzeum Narodowego w Warszawie. Kolejny referent - prof. dr hab. Jacek Puchalski (Uniwersytet Warszawski) - wygłosił prelekcję pt. „Biblioteki polskie za granicą zagrożone likwidacją i rozproszeniem", która była wynikiem szeroko zakrojonych badań nad współczesnymi księgozbiorami polonijnymi (por. B. Bieńkowska, E. Maruszek, J. Puchalski, Współczesne księgozbiory polskie za granica, informator, t. 1: Polskie i polonijne księgozbiory instytucji, Warszawa 2009). Autor zwrócił uwagę, że wśród 746 bibliotek tylko nieliczne mają fachową i należytą opiekę. W dużej mierze bibliotekarzami są tu wolontariusze, którzy dawno osiągnęli wiek emerytalny. Do czynników decydujących o likwidacji zaliczył m.in. kwestie finansowe i brak zainteresowania zbiorami.

Konferencję zamknął Patryk Sapała (Instytut Historii Uniwersytetu Warszawskiego) z referatem „Powojenne 
pozostałości zbiorów Przeździeckich". Niestety, autor nie skupił się na bibliotece ordynackiej, lecz na kolekcji dzieł malarskich. Jedynie skromny fragment prelekcji został poświęcony archiwaliom rodzinnym, które w sposób sygnalny zobrazowały preferencje kolekcjonerskie rodziny Przeździeckich.

Malborskie spotkanie naukowe zamknęła dyskusja. Główny apel z sali był skierowany do bibliotekarzy zbiorów specjalnych i dotyczył potrzeby prowadzenia rejestracji proweniencji występujących w księgozbiorach historycznych. W czasie wymiany zdań wynikł problem prawowitych właścicieli ksiąg przechowywanych w książnicach polskich i ich ewentualnej rewindykacji po ujawnieniu zapisek własnościowych. Tu kolejny wykład wygłosiła H. Łaskarzewska na temat przekazywania zbiorów, przytaczając spektakularne przykłady tych zwrotów. Jako kolejny głos $\mathrm{w}$ dyskusji zabrał R. Nowicki, który uzupełnił informacje do referatu M. Spandowskiego, dotyczące liczby inkunabułów w zbiorach Biblioteki Uniwersyteckiej w Poznaniu. Odpo-

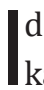
dea wolnego dostępu do nauki, edukacji czy kultury, realizowana w ramach ruchu Open Access (dalej: OA), jest już powszechnie znana. W ogromnej większości polskie środowisko naukowe docenia wagę zwiększania publicznej dostępności do dzieł nauko- wiadając na zarzuty, prelegent dokonał również niezbędnej korekty dotyczącej działalności Aleksandra Birkenmajera i innych dyrektorów bibliotek naukowych w okresie po II wojnie światowej. Dyskusję zamknęła polemika między M. Spandowskim a A. Wagnerem na temat znaczenia i wykorzystania zbiorów Biblioteki Polskiej w Paryżu oraz proweniencji wybranych fragmentów jej kolekcji.

Konferencję należy zaliczyć do udanych, ponieważ była okazją do prezentacji bieżących badań nad księgozbiorami historycznymi, które uległy rozproszeniu po II wojnie światowej, co stanowiło spójną tematycznie całość. Pozostaje mieć nadzieję, że będzie to spotkanie cykliczne i że w najbliższym czasie ukaże się publikacja będąca pokłosiem tego ważnego dla środowiska spotkania.

\section{Bernardeta Iwańska-Cieślik}

Katedra Informacji Naukowej i Bibliologii Uniwersytetu Kazimierza Wielkiego w Bydgoszczy

\section{Debata o otwartej nauce i nowych modelach publikowania czasopism naukowych (Toruń, 30 października 2012 r.)}

DOI: 10.12775/TSB.2013.016 